\title{
Development of a Batch-Type Biogas Digester Using a Combination of Cow Dung, Swine Dung and Poultry Dropping
}

\author{
Olawale 0. Olanrewaju*, Obafemi O. Olubanjo \\ Department of Agricultural and Environmental Engineering, School of Engineering and Engineering Technology, \\ Federal University of Technology, Akure, Nigeria \\ Email: *waleolanrewaju166@yahoo.com
}

How to cite this paper: Olanrewaju, O.O. and Olubanjo, O.O. (2019) Development of a Batch-Type Biogas Digester Using a Combination of Cow Dung, Swine Dung and Poultry Dropping. International Journal of Clean Coal and Energy, 8, 15-31.

https://doi.org/10.4236/ijcce.2019.82002

Received: April 24, 2019

Accepted: May 28, 2019

Published: May 31, 2019

Copyright () 2019 by author(s) and Scientific Research Publishing Inc. This work is licensed under the Creative Commons Attribution International License (CC BY 4.0).

http://creativecommons.org/licenses/by/4.0/

(c) (i) Open Access

\begin{abstract}
The overdependence on crude oil in African countries warrants the need for alternative sources of energy. A 56-litre-capacity biogas digester was designed, fabricated and evaluated. Investigations were made into the production of biogas from the mixture of cow dung, swine dung and poultry dropping. Standard equations and models were used in the design of the components of the manually operated digester. The digester temperature, ambient temperature and $\mathrm{pH}$ were monitored during the experiment. The proximate analysis showed that volatile solid, total solid and moisture content for the mixed substrates at the initial stage were: $64.7 \%, 83.5 \%$ and $13.5 \%$ respectively. Similarly, at the digestion stage, the volatile solid, total solid and moisture content were: $54.1 \%, 22.6 \%$ and $74.4 \%$ respectively. Advancement of decomposition leads to gradual increasing $\mathrm{pH}$ value from 7.2 to 7.4 , which indicates the stability of organic matter. The moisture content on a wet basis was initially $13.5 \%$. This value latter increased to $74.4 \%$. On the average, $15 \mathrm{~kg}$ of mixed substrates with 25 litres of impure water produced biogas within 25 days of digestion. The gas produced from mixed substrates became flammable with blue flame after 16 days of production, indicating that the ratio of methane gas generated with the three mixtures of fresh animal waste was higher than other gases produced.
\end{abstract}

\section{Keywords}

Biogas, Renewable Energy, Cow Dungs, Swine Dungs, Poultry Droppings, Slurry, Anaerobic Decomposition

\section{Introduction}

The rising cost of petroleum products is a serious problem facing most develop- 
ing countries of the world including Nigeria. The extent of increase in industrialization and population has resulted in excessive energy demands from both rural and urban dwellers, raising the need for exploration of other natural sources of energy [1]. Hence, conversion of agricultural wastes into biogas could be leeway to solving some of these energy problems [2] [3]. However, due to epileptic electricity supply in Nigeria which has greatly reduced daily income and lead to abnormal hike in foreign currency on daily market stock, it is therefore important that Nigerians should embrace an alternative way by which electricity and cooking gas can be generated [4] [5]. It is also important to be more conscious of environmental sanitization, as indiscriminate disposal of waste results in health issues and environmental disasters. The concept of waste management involving the collection of generated waste into modified tanks for recycling purpose to produce biogas, will be of great advantage to the nation's rising population [6] [7]. Furthermore, in accomplishing the sustainable developmental goal of ensuring access to affordable, reliable, sustainable and modern energy in Nigeria, rural communities with farming as a major occupation, lacking access to electricity, can be brought to lime-light through the adoption of biogas system for generation of energy for household usage. International Energy Agency reported in EIA [8] that the electrification rate in Nigeria is 45 percent leaving approximately 93 million people in Nigeria without access to electricity and 115 million people in Nigeria relying on traditional biomass and waste as their main sources of energy for domestic uses.

Achieving solutions to probable scarcity of fossil fuels and environmental problems that the world is facing today requires long-term potential actions for sustainable development [9] [10] [11]. The dependence on fuel wood for the domestic energy supply has aggravated deforestation, with annual deforestation rate estimated at $3 \%$, which is equivalent to the loss of 410,000 hectares of forested land annually. Indoor air pollution from burning biomass in open fires, usually without chimneys is a major concern, as it results in respiratory diseases and premature deaths [2] [6]. Thus, the need for the utilization of more agricultural wastes as an alternative energy source is apparent. Globally, there has been an increasing call for diversification in oil production and consumption by economist, environmentalist and health practitioners. However, Nigeria's dependence on oil remains unwavering, as it provides $10.04 \%$ of the Gross Domestic Product, $92 \%$ of foreign exchange earnings, and about $78.5 \%$ of budgetary revenues [12]. These petroleum products are not available and affordable to rural community to meet energy needs. Hence, these petroleum products are not available and affordable to rural community to meet energy needs, hence, the need for an alternative source of energy for domestic use [2] [13]. A possible alternative to fossil fuels is the production of biogas by anaerobic digestion of residues, waste and energy crops. The use of cheap locally sourced materials and its reduction of green gas emissions are of enormous advantage.

Globally, cow manure is used as feedstock for many digesters currently run- 
ning to produce biogas (methane) for energy recuperation [5] [14]. Although convenient and feasible, it has been recognized that using cow manure alone may not achieve the most efficient production of biogas due to its inherent deficiency of carbon (low carbon/nitrogen ratio). Mid-West Plan Service Publication [15] reported the carbon/nitrogen $(\mathrm{C} / \mathrm{N})$ ratio of cow manure as eight (8) with regards to the cow growth stages, this value is relatively low for an anaerobic digester to function efficiently in the utilization of the manure nutrients and maximization of methane yields. Dioha et al. [16] achieved an optimal C/N range of 15.5/1 to 19/1 for cow manure digestion in terms of maximum methane production by adding either urea or glucose to the flask digesters.

Several researchers have conducted several studies on the optimization of biogas yield in Anaerobic digestion as reported by [1] [5] [7] [9] [13] [17] [18]. Similarly, swine manure has a $\mathrm{C} / \mathrm{N}$ ratio of $6-8$ [15]. The greatest methane production is achieved when its $\mathrm{C} / \mathrm{N}$ is adjusted to $25 / 1$ using glucose. Particularly, using urea and/or glucose to change the $\mathrm{C} / \mathrm{N}$ ratio in digested content cannot be an economically sustainable method to facilitate methane generation from large scale digesters [16] [19]. However, the productivity of anaerobic digestion process can be enhanced by optimizing the substrate $\mathrm{C} / \mathrm{N}$ ratio. Therefore, it is worth the effort to research alternative additives to accomplish the $\mathrm{C} / \mathrm{N}$ ratio modification in the digester feedstock. Crop residue such as maize husks and cassava peels are produced in large quantity in Nigeria every year, which, due to its organic nature can be a valuable alternative feedstock for biogas production. The benefit of co-digesting plant material with animal manure can provide buffering capacity and a wide range of nutrients while the added plant materials with high carbon content can improve the $\mathrm{C} / \mathrm{N}$ ratio of the feedstock, thus potentially improving methane yields [20] [21] [22]. Because of its large unexploited benefits for biogas production, via anaerobic digestion, crop residues certainly deserve research attention for use as a feedstock for co-digesting with cow manure.

\subsection{Developments in Anaerobic Digestion of Organic Solid Waste}

Anaerobic digestion is a microbial process involving the biodegradation of organic matter by association of microorganisms in the absence of oxygen, resulting in the formation of biogas which consists of methane and carbon dioxide, and effluent consisting of the remaining solids and liquids [23]. It occurs naturally in wetlands, marshes and a principal agent in degradation of bio-waste in landfills, it is also present ruminants' digestive tracts [14] [24].

\subsection{Stages Involved in Anaerobic Digestion}

Anaerobic Digestion occurs in four stages which include: hydrolysis, acidogenesis, acetogenesis and methanogenesis. The degradation stages are carried out by different consortia of microorganisms, which partly stand in syntrophic interrelation and place different requirements on the environment [23] [25]. 


\subsubsection{Hydrolysis}

During anaerobic digestion, hydrolysis is the first step in which long-chain organic molecules are broken down by hydrolytic bacteria into their constituent monomers, complex polymers from organic biomass which are inaccessible to microorganisms are broken down. During this process, hydrolytic bacteria are able to secrete extracellular enzymes (cellulase, xylanase, amylase, protease, lipase) that convert carbohydrates, lipids, and proteins into sugars, long chain fatty acids, and amino acids, respectively [26] [27], products of this process are able to diffuse through the cell membranes of acidogenic microorganisms [25]. Generally, hydrolysis is best achieved at an optimum temperature between $30^{\circ} \mathrm{C}-50^{\circ} \mathrm{C}$ and an optimum $\mathrm{pH}$ of 5 - 7 [28] [29].

\subsubsection{Acidogenesis (Fermentation)}

Acidogenic microorganisms absorb the products of hydrolysis through their cell membranes, then ferment them into volatile fatty acids (VFAs) such as acetate, propionate, and butyrate. Short-chain VFAs (i.e., propionate, butyrate, and valerate) are converted into acetate via the process termed acetogenesis [25]. Acidogenesis is perceived to progress at a quicker rate than all other stages of anaerobic digestion [23]. The degradation of these compounds results in the production of $\mathrm{H}_{2}, \mathrm{CO}_{2}$, alcohols, organic acids, organic-nitrogen compounds, and organic-sulfur compounds. The most important of the organic acids is acetate since it can be used directly as a substrate by methanogenic bacteria [29] [30] [31].

\subsubsection{Acetogenesis (Acidification)}

During acidogenesis, some of the acetate produced is already rendered into a suitable substrate for acetoclastic methanogenesis [25]. However, other higher VFAs produced are not accessible to the methanogenic microorganisms. Acetogenesis is the process by which these higher VFAs and other intermediates are converted into acetate, with hydrogen also being produced [32].

Acetogenic bacteria break down low molecular weight volatile fatty acids and alcohols into acetate, hydrogen gas and carbon dioxide. Acetate is not only produced through the fermentation of soluble organic compounds but also through acetogenesis [33]. Hydrogen gas is a major product of this process and excessive partial pressure is proven to be harmful to the acetogenic microorganism [30] [34]. This conversion process can only be thermodynamically favourable if the partial hydrogen pressure is kept low. However, due to the presence of hydrogenotrophic methanogens, there is a rapid consumption of hydrogen, thereby maintaining the hydrogen partial pressures at a favorable level to acetogenesis by creating an exergonic reaction [35].

\subsubsection{Methanogenesis (Methane Formation)}

This is the final stage of anaerobic digestion, where the methanogenic microorganisms produce methane by consuming all forms of intermediates compounds found in the system. The methanogenic bacteria convert acetic acid and hydrogen into $\mathrm{CO}_{2}$ and methane. This microorganism requires a higher temperature 
and $\mathrm{pH}$ than previous stages of anaerobic digestion [24]. Methane is formed around $66 \%$ from acetate by means of acetate decarboxylation, proceeded by acetoclastic methanogenic bacteria (e.g. Methanosaeta spp and Methanosarcina spp.) and 34\% from carbon dioxide reduction by hydrogen, catalyzed by hydrogen-utilizing (hydrogenophilic) methanogenic bacteria [28] [36]. These bacteria are strict anaerobes and require a lower redox potential for growth than most other anaerobic bacteria [20]. Methanogens tend to have a significantly slower regeneration time than other microorganisms in anaerobic digestion, upwards of 5 - 16 days [23]. Although, Methanococcus maripaludis, among other hydrogenotrophic species is reported to possess a doubling time of only two hours [31]. Chemical reactions during methanogenesis can be summarized as in (1) and (2) below:

$$
\begin{gathered}
2 \mathrm{CH}_{3} \mathrm{CH}_{2} \mathrm{OH}_{(\mathrm{l})}+\mathrm{CO}_{2(\mathrm{~g})} \rightarrow \mathrm{CH}_{4(\mathrm{~g})}+2 \mathrm{CH}_{3} \mathrm{COOH}_{(\mathrm{l})} \\
\mathrm{CH}_{3} \mathrm{COOH}_{(\mathrm{ag})} \rightarrow \mathrm{CH}_{4(\mathrm{~g})}+\mathrm{CO}_{2(\mathrm{~g})} \\
\mathrm{CO}_{2(\mathrm{~g})}+4 \mathrm{H}_{4} \rightarrow \mathrm{CH}_{4(\mathrm{~g})}+2 \mathrm{H}_{2} \mathrm{O}_{(\mathrm{l})}
\end{gathered}
$$

In digester, the termination in the supply of biogas signifies the end methanogenesis, which can take between 25 - 40 days [19] [29]. The Volatile solid content could then ben analyzed to assess the degree of digestion.

Bio-digestion is a complex fermentation process birth by the symbiotic association of different bacterial types. The activities and products of one set of bacteria support the other and vice versa [29]. Practically, fermentation processes involve the metabolic actions of the various bacteria acting in synchronization. A group of microorganisms serves as the substrate for the next resulting into several interdependent, complex sequential and parallel biological reactions [27] [37]. When the acid-producing bacteria use up the oxygen to create light compounds, it creates an anaerobic environment for the methanogens as well as a compound of low molecular weight. On the other hand, methane-producing microorganisms use up the intermediates of the acid-producing bacteria from the system thereby eliminating the possibility of creation of toxic conditions for the acid-producing microorganisms.

\subsection{Conditions for Anaerobic Digestion}

Two of the most important factors for proper anaerobic digestion and methane production are temperature and $\mathrm{pH}$, irregularities of these factors result in challenges in digestion, particularly the rates of hydrolysis and methanogenesis. Digesters perform well in warmer atmospheres [6] [10], although anaerobic digestion is not absolutely terminated at a lower temperature, overall methane production is reduced as methanogenesis is impeded. Selected chemicals such as sodium nitrate, lime, sodium (bi-)carbonate and quick lime can be added slowly to adjust the $\mathrm{pH}$ of the system without having an adverse effect on the bacteria [31] [38].

The solid concentration, which is the amount of fermentable material of the 
feed in a unit volume of slurry, affects the rate of digestion as well. Increase in slid content inhibits the mobility of methanogens within the substrate, affecting the biogas yield [29]. Ordinarily, 6\% - 9\% solids concentration is best suited for biogas production [13]. The amount of substrate fed per unit volume of digester capacity per day, regarded as the loading rate has an impact on the rate of digestion. Overloading of the digester will result in high gas yield initially which reduces abruptly due to inhibition, which is restraint in the multiplication of methanogenic bacteria as compared to acidogenic bacteria thereby limiting the gas produced.

In addition, in ensuring adequate growth of bacteria in anaerobic digestion, a regular supply of organic substances as a source of carbon and nutrients is important, they also require certain mineral nutrients in addition to nitrogen, Sulphur, carbon, oxygen and hydrogen. These elements are largely found in agricultural residues and wastes [6]. The duration of retaining the slurry in the digester influences the rate of digestion. The average time spent by the input slurry, which is the Hydraulic Retention Time (HRT), if shorten could result in the collapse in the bacterial population while achieving a longer HRT requires larger digester volume [17] [30].

Furthermore, the ratio of carbon to nitrogen in the digester influences the operation of the bacteria. An optimum carbon/nitrogen $(\mathrm{C} / \mathrm{N})$ ratio for anaerobic bio-digestion is between 20:1 and 30:1 [16] [19]. In the situation of relatively high ratio than the optimum range, methanogenic bacteria will exhaust the nitrogen rapidly leaving the remaining carbon in the material, thereby reducing the gas production. Conversely, for a relatively low ratio than the optimum range, a large amount of ammonia will be formed, thereby raising the $\mathrm{pH}$ of the system above 8.5, and inhibiting the microbes limiting gas production. Also, the presence of toxic substances such as mineral ions, heavy metals inhibits the activities of methanogenic bacteria in the digester. However, a small quantity of mineral ions (ammonium, Sulphur, sodium, potassium) can activate the growth of bacteria, while a large amount of these ions will have a toxic effect [16] [31] [39].

Moreover, a continuous stirring of the digester content is vital in ensuring close contact between the microorganisms and substance which ultimately improves the digestion process. Agitation can be achieved by daily feeding of the digester instead of periodicals mixing to create the same effect [1] [4] [7]. All processes in anaerobic digestion do not require oxygen, and they are indeed very sensitive to the presence of oxygen, as the breakdown of organic materials in the presence of oxygen, will produce carbon-dioxide instead of the desired methane gas. Hence, an air-sealed digester is essential for optimum digestion [39]. Additionally, an optimal moisture content, of about $90 \%$ of the total volume of feedstock is required for the effective performance of bacteria in the digester [19] [20], as metabolic activities involved in the digestion of organic matter requires water. Excess water reduces the rate of production, while in adequate water results in accumulation of acetic acids which inhibits the digestion process [14] [29].

This research is aimed to help our people to reduce the over-dependence on 
liquefied fossil fuels, with the lowest possible cost. This project will also provide an alternative mean of keeping our environment clean from animal waste. Others include conservation of our natural resources like the forest, natural gas and replenishment of the exploited farmland. The effluent, after gas has been evolved, can be used as manure which is a good source of organic fertilizer for the farmer. The gas produced by biogas is an alternative for energy production and utilization thereby going a long way to conserving our natural gas [26]. It will also serve as a means of managing our environment against unpleasant odour by the evacuation of animal waste or dung that would have resulted in air pollution, which would have impaired our breathing. This animal waste as reported by several researchers possesses the potential to be used as biofuel (Table 1). Above all, this project will help to make cooking easy in our individual homes and reduce excessive exposure to hot radiation caused by firewood.

\section{Materials and Methods}

\subsection{Materials}

The Digester was filled with a mixture of the substrates from the combination of Cow Dung (CD), Poultry droppings (PD), and Swine Droppings (SD). The compositions of the Digesting Materials were collected from abattoir within Akure metropolis and Federal University of Technology Akure (FUTA) agricultural research farm, each of which was measured in kilograms $(5 \mathrm{~kg})$ and mixed with impure water to form slurry.

The digester is circular in shaped and consists of the inlet valve, the outlet valve, the fermentation section and the stirrer as shown in Plate 1 below. The stirrer is manually powered for even and easy stirring of the mixture to aid fermentation. Also connected to the top of the digester is a pressure gauge to indicate the amount of gas produced in the digester. Plate 1 showed the complete system and how the units are interconnected. The biogas plant consists of two major components (the digester tank and the storage tank) which were connected by hose. The digester tank consists of inlet valve at the top, where the substrates were loaded and also locked afterwards to prevent the escape of gas and

Table 1. Relative biogas generation from various materials.

\begin{tabular}{cc}
\hline Organic material & Biofuel (L/Kg/dry matter) \\
\hline Cow manure & 40 \\
Sheep manure & 94 \\
Savage sludge & 65 \\
Water lettuce & 105 \\
Eupatorium odoratum & 256 \\
Cassava leaf & 55 \\
Water hyacinth (Eichhornia crassipes) & 98 \\
Poultry dung & 128
\end{tabular}

Source: [7] [9] [21] [40]. 


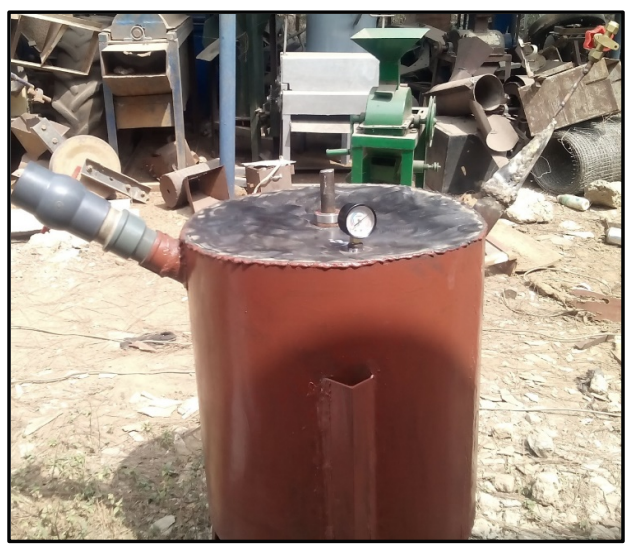

Plate 1. Biogas digester.

for easy fermentation process to occur. It also has an outlet at the base of the digester where the mixture of effluents and substrate is being released from the tank for further use in crop fertilization. The digester tank also has a pressure gauge at the top, this help to determine the amount of gas produced. The digester tank also has a filter that contains the filtering substance which helps in the purification of the biogas produced. The gas produced is being controlled by a set of valves attached to the digester. The gas produced is transported to the burning point by the hose.

\subsection{Design Consideration}

Biogas digester is a convectional machine that would interact with different waste such as plant and animal waste and also micro-organism in the process of production, with some high degree of strength, pressure and precision, with consideration for cost and maintainability. Ideally, the materials used for construction should be durable and strong enough to retain its shape under pressure and heat, and must be easy to dismantle and couple back during cleaning. The factors like pressure which tends to blast the cylinder and corrosion by using thick mild steel for the construction were considered.

High consideration was given to the strength in designing the biogas unit because of internal forces of the substrate to be used and pressure of the produced. Torsional stress and strain factor were adequately considered. Also, the size was taken into account to ensure the ease of moving the machine from one place to another. The bearing capacity to withstand the internal load of the material and external force of the environmental influence e.g. weather, and corrosion resistance were reviewed. Cost of production of the biogas unit as well as affordability of the unit, was also considered during design to encourage adoption of the technology.

\subsection{Design Analysis}

The main objective of the design is for energy production, maximizing the primary variables such as biodegradability of the materials, concentration of the 
feed, kinetic constants, Retention time, that affects the production of the biogas is important [18]. In designing a biodigester, the total volume of digester, $V_{T}$, volume of gas storage, $V_{g}$, retention period, $R_{t}$ and the amount and type of organic waste to be digested are majorly considered according to experiment carried out by [6] [7] [41].

\subsubsection{Digester Tank Capacity Determination}

According to [7] and [9], the Total Volume of the digester, $V_{T}$ is the addition of the Slurry volume, $V_{s}$ and the storage capacity of the gas, $V_{g}$.

$$
V_{T}=V_{s}+V_{g}
$$

The digester was fed once, but the calculation was based on daily feeding with the design criteria of 25 days retention period, $5 \mathrm{~kg}$ of $\mathrm{CD}, \mathrm{PD}$ and $\mathrm{SD}$ each was fed into digester, with an equal volume of water for mixing, waste and water are in 1:1 [7]. $1 \mathrm{~kg}$ is equivalent to 1 liter; using $15 \mathrm{~kg}$ of waste. A total of $15 \mathrm{~kg}$ is fed for 25 days at a rate of $0.6 \mathrm{~kg} /$ day.

Volume of Slurry, $V_{s}=15$ ltrs of waste +15 ltrs of water $=30$ litres

Volatile solid loading rate is a measure of the biological conversion of the anaerobic digestion system [29]. For the mixture of animal and kitchen waste, the rate of biogas production is about $0.5 \mathrm{~m}^{3} / \mathrm{kg}$ of added volatile solid [42]. The amount of biogas generated each day $\left(\mathrm{m}^{3} /\right.$ day) will be calculated using Equations (2) and (3) below, on the basis of the daily substrate input (volatile solids content) and specific gas yield of the substrate [6] [29] [41], Hence;

Daily gas production

$=$ volatile solids content $\times$ the specific gas yield (solids)

$=0.6 \mathrm{~kg} /$ day $\times 0.50 \mathrm{~m}^{3} / \mathrm{kg}=0.3 \mathrm{ltrs} /$ day

Total volume of gas after 25 days $=0.3$ ltrs $/$ day $\times 25$ days $=7.5$ litres

Using Equation (1), the total volume of digester, $V_{o}$ is given as 37.5 litres. The maximum loading capacity of the digester must not exceed $80 \%$ of the total volume of the digester to at least give $20 \%$ of the total volume for slurry rise and for biogas as reported by [6]. The total volume of $V_{T}$ is, thus, given in Equation (4):

Total volume of Digester, $V_{T}=V_{o} \times 1.25=37.5 \times 1.25=46.875$ litres

In designing a cylindrical digester tank of 48 litres capacity, with height $0.7 \mathrm{~m}$. Equation (5) is used below as used by [11], the diameter is given as $0.094 \mathrm{~m}$

$$
V=\pi r^{2} h
$$

\subsubsection{Shaft Design}

In designing the shafts for the machine, considerations were given to the following factors:

- Since deflection is typically the design limiting issue, higher strength steel such as low carbon steel was used.

- To minimize both deflection and stresses, the shaft length was kept as short as possible and over hangs was also minimized. 


\subsubsection{Design for the Diameter of Shaft/Stirrer}

The diameter of shaft for the stirrer can be determined using the equation below:

$$
d^{3}=\frac{16}{\pi S_{s}} \sqrt{\left(M_{t} k_{t}\right)^{2}+\left(M_{b} k_{b}\right)^{2}}
$$

where $S_{s}=$ allowable shear stress of metal with key way $=40 \times 10^{6} \mathrm{~N} / \mathrm{m}^{2}$

$M_{b}=$ maximum bending moment $=25.61 \mathrm{~N} \cdot \mathrm{m}$

$M_{t}=$ torsion moment $=22.3 \mathrm{~N}$

$k_{b}=$ combined shock and fatigue factor applied to bending moment $=1.5$

$k_{t}=$ combined shock and fatigue factor applied to torsional moment $=1.0[4]$

\subsection{Methods}

\section{Collection of Substrates}

The substrates (materials used for biogas production) are poultry droppings, swine droppings and cow dung waste were collected locally within the Federal University of Technology, Akure. The substrates were mixed together in the same proportions with water of 15 litres, the individual substrate was weighed to be 5 kilograms each, and these were mixed together and loaded into the digester. An equal volume of water is used in mixing each substrate used $(\mathrm{CD}, \mathrm{PD}$ and SD) to form slurry.

\subsection{Production of Biogas}

The substrate was left in the digester for two weeks for anaerobic digestion; biogas was produced after which it was stirred so that the gas can evolve. The stirring is done by rolling the handle manually for about 5 to 10 minutes. The outlet valve is then opened for collection of gas produced. Gases produced were burnt using gas lit.

\subsection{Measurement of Parameters of the Digester}

The temperature of the digester was maintained within the allowable temperature ranges for optimum gas production being; mesophilic, cycrophilic and thermophilic temperature ranges. Temperature reading was taken twice daily both in the morning and evening, with a thermocouple placed inside the digester. Digital $\mathrm{pH}$ meter was used to measure the $\mathrm{pH}$ daily.

\section{Results and Discussion}

The feedstocks were analyzed for temperature, total solid, ash content, volatile solid, $\mathrm{pH}$, moisture content. The total solid, volatile solid and moisture content were determined in accordance with the method provided in section $2540 \mathrm{E}$ of American Public Health Association-Standard Methods as executed by [6].

\subsection{Analysis of Physiochemical Properties}

Table 2 below shows the physicochemical properties of the mixed substrates from laboratory analysis. Physicochemical properties of mixed substrate (fresh 
Table 2. Physicochemical properties of Fresh mixture of Cow Dungs, Swine Dungs and the Poultry Droppings.

\begin{tabular}{ccc}
\hline Parameters & Fresh Substrates & Digested Substrates \\
\hline Total solids (\%) & 83.5 & 22.6 \\
Moisture content (\%) & 13.5 & 74.4 \\
Volatile solids (\%) & 64.7 & 54.1 \\
Ash content (\%) & 34.6 & 45.6 \\
$\mathrm{pH}$ & 6.6 & 7.2 \\
Temperature $\left({ }^{\circ} \mathrm{C}\right)$ & 30.3 & 29.5 \\
\hline
\end{tabular}

chicken droppings, cow dung and swine dung) at exact day of digestion and after the experiment are shown. The results of the physicochemical properties of mixed substrates over a period of 25 days show a decrease in the total solids and volatile solids from $83.50 \%$ to $22.60 \%$ and $64.70 \%$ to $54.10 \%$ respectively, which may be due to the utilization of the wastes by the microorganisms. This is in agreement with the result of [17] and [27], who explained that there was a reduction in the total solids and volatile solids reduced as methane yield increases. The retention period for biogas production was twenty-five days. This may be due to the accumulation of acids, exhaustion of nutrient or production of auto-toxic substances by the microbes because this process is a batch culture system.

It is obvious that the moisture, ash content and $\mathrm{pH}$ increased significantly ( $\mathrm{p}<$ $0.05)$ while the total solids, volatile solids and the temperature reduced significantly $(\mathrm{p}<0.05)$ as also observed by Nwankwo et al. [11]. Although the total solid content of the waste used was above the optimum range of $7 \%-9 \%$ recommended by Nwankwo et al. [11] and Deepanraj, et al. [37] in order to avoid overloading the system. However, the digestion process was efficient in removing the total solid.

\subsection{Effects of Temperature and $\mathrm{pH}$}

Figure 1 and Figure 2 shows the variation in $\mathrm{pH}$ and temperature of the mixed substrate with respect to the retention time of 25 days respectively. $\mathrm{pH}$ reading recorded was within the range of $6.7-7.4$, with the mean $\mathrm{pH}$ at $6.90 \pm 0.18$. From the experiment, it was revealed that the acidity in the digester caused the very low yield of biogas in the first 7 days of retention. The result was compared to some other results obtained previously by Musa and Raji [10] from the analysis of biogas from three organic wastes, Ukpabi [30] who produced biogas from cow dung and food waste, Nwanko et al. [11] who generated biogas from kitchen waste and cow dung, and Otun et al. [7] who evaluated the production of biogas from the co-digestion of animal, food and fruit waste.

During the early stage of decomposition, the acid-forming bacteria were found to be breaking down the substrate with volatile fatty acids produced. This changed the values of the general acidity for the digesting material with the value 


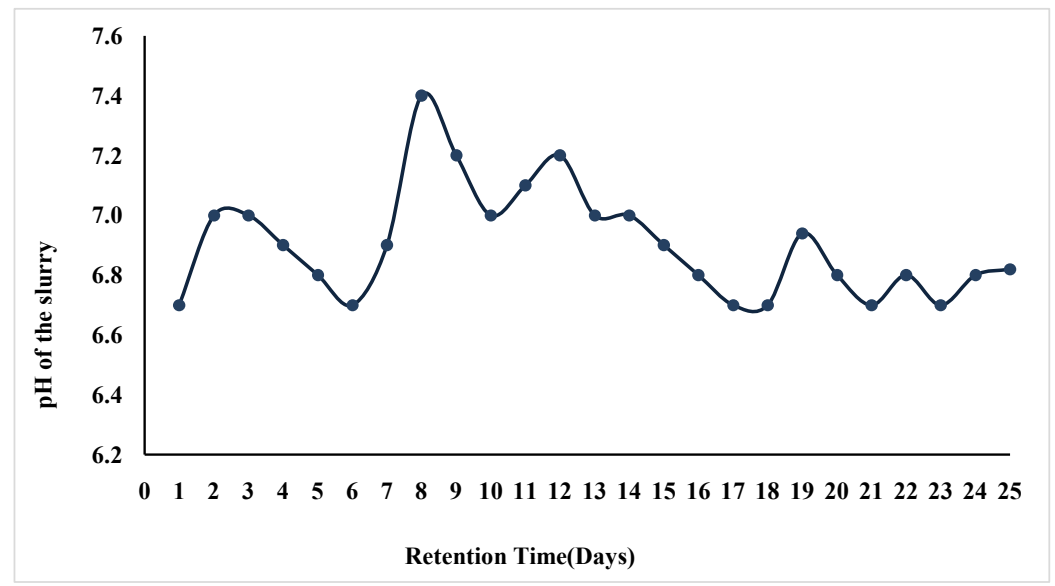

Figure 1. Variation of mixed substrates $\mathrm{pH}$ with retention time (Days).

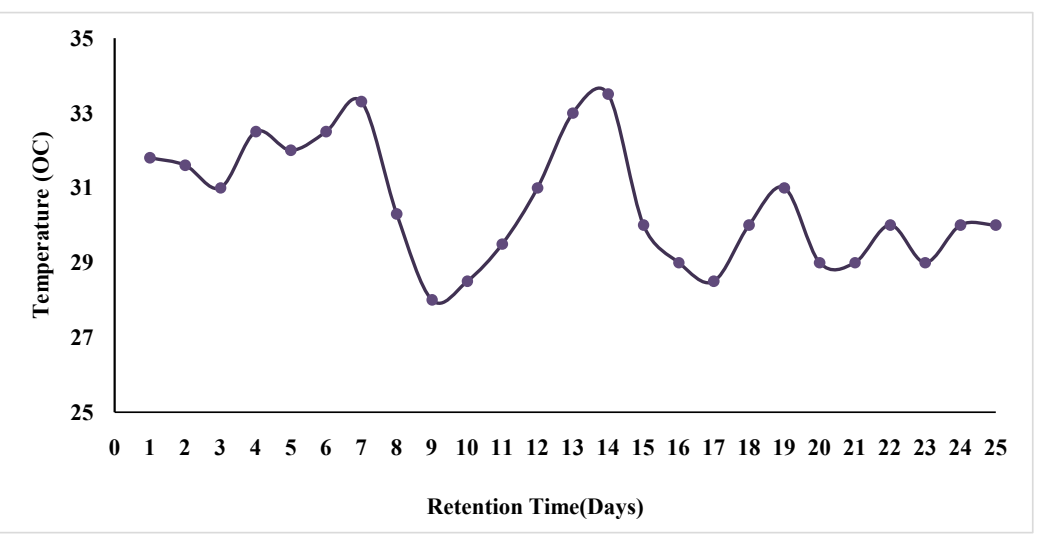

Figure 2. Variation of mixed substrate slurry temperature with retention time (Days).

of the $\mathrm{pH}$ falling below neutral [6] [38]. These changes assisted the microorganisms in the system to perform well which led to an increase in the production of the biogas. On the first week, the lower level of the $\mathrm{pH}$ recorded by mixed substrates explains the first stage of anaerobic digestion-hydrolysis and acetogenesis. Acetogenesis involves the conversion of volatile fatty acids present in the substrate into simpler organic acids including acetic acid, propionic acid and ethanol. This acidic intermediate naturally causes a drop in the hydrogen ion concentration of the slurry in the bio-digester which was observed to fall as low as 6.2 after the first two weeks of digestion. As the weeks went by, the organic acids produced during acetogenesis (majorly acetic acid) were acted upon by methanogenic bacteria and hence broken down into methane and carbon dioxide; the major constituents of biogas. The $\mathrm{pH}$ begins to rise as the acetic acid is converted into biogas. It should be noted that $\mathrm{pH}$ affects the growth of microbes during anaerobic fermentation/digestion. Otun et al. [7] reported that it is important to maintain the $\mathrm{pH}$ of an anaerobic digestion process between $6-8$, in order not to inhibit the growth of methanogens. It was also observed that the changes in the $\mathrm{pH}$ value also resulted in changes in the volume of gas produced, as consistency in the higher range of $\mathrm{pH}$ favours the methanogenic bacteria. 
These bacteria are inhibited in $\mathrm{pH}$ greater than 8 or less than 5 as reported by Nwanko et al. [11] and Okewale [40].

Figure 2 shows the slurry temperature trend of the mixed substrates. The ambient temperature varied from $20^{\circ} \mathrm{C}$ and $32^{\circ} \mathrm{C}$ with the mean temperature at $29.26 \pm 1.58^{\circ} \mathrm{C}$, this fluctuation is as a result of climatic conditions, which in turn affects the slurry at each stage of digestion. The mesophilic $\left(21^{\circ} \mathrm{C}-38^{\circ} \mathrm{C}\right)$ is the temperature range that was identified from the slurry temperature. This is similar to the result observed by Otun et al. [7] and Nwanko et al. [11]. From the results obtained, anaerobic bacteria thrive best at a mesophilic temperature of about $34^{\circ} \mathrm{C}$ [27] [40]. Temperature is observed by many biogas researchers as a critical condition for anaerobic digestion, as methanogenic bacteria operate most efficiently at temperatures $30^{\circ} \mathrm{C}-40^{\circ} \mathrm{C}$ [37]. The ambient temperature affects the rate of digestion due to the direct contact of the outside walls of the digester and the atmosphere [13] [17]. It was observed that the volume of gas produced increases with increase in temperature and as temperature drops, the rate of biogas production declines to agree with Gaby [38].

\subsection{Flammability of the Gas}

Biogas is a flammable gas produced when organic materials are fermented under anaerobic condition. It contains mainly methane and carbon (IV) oxide with traces of hydrogen sulphide and water vapour. Biogas burns with a pale blue flame and it has a calorific value of between $25.9 \mathrm{~J} / \mathrm{m}-30 \mathrm{~J} / \mathrm{m}$, depending upon the proportions of methane and other constituent gases [6] [11]. During the research, an increase in the pressure gauge was observed after a week of retention, indicating an occurrence of biochemical reaction due to microbial activities resulting in the production of biogas. The combustibility of the biogas produced was determined out by igniting matches near the gas opener as experimented by [6] and [10]. The result gave a pop sound with flames. The test was repeated after 25 days of digestion. The test proved positive for the gas burnt with a blue flame, producing no soothes.

\section{Conclusion}

The effective implementation of biogas digester for production of biogas from the decomposition of agricultural waste offers a reliable solution for economic development energy and environmental sustainability. A biogas digester consisting of inlet opener, outlet opener, a stirrer handle, spikes and cylindrical chamber was designed, fabricated and evaluated. The result of this research showed that many of the microorganisms associated with the fermentation of cow dung', swine dung' and poultry dropping originated from the substrate used and it was established that temperature variation, $\mathrm{PH}$ and Concentration of Total solid, are some of the factors that affected the volume yield of biogas production. The biogas yield was dependent on the temperature of the environment where the digester was placed. The $\mathrm{pH}$ on the other hand was affected by the 
Carbon:Nitrogen (C:N) ratio of the mixed substrates. An increase in the amount of gas produced with respect to the retention time of twenty-five (25) days, yielding a reasonable amount of gas. The quantity and quality of biogas produced after the $25^{\text {th }}$ day makes the biomass to be regarded as the best mixture and the best C:N ratio for optimized biogas production. In conclusion, the mixed substrates produced biogas faster than other substrates in mixture when compared to findings from literatures. The cost of production of the digester was N38, 805.75; this is considered a price affordable to the lower and middle class. One of the limitations to the research and adoption of technology is the availability and regular supply of feedstock.

\section{Conflicts of Interest}

The authors declare no conflicts of interest regarding the publication of this paper.

\section{References}

[1] Adebayo, A., Adeleke, S., Tiekuro, E. and Omugbe, E. (2019) The Production of Biogas from Cow Dung for Powering a Motor Vehicle Tyre Tube. Journal of Energy Research and Reviews, 2, 1-5. https://doi.org/10.9734/jenrr/2019/v2i229733

[2] Gujba, H., Mulugetta, Y. and Azapagic, A. (2015) The Household Cooking Sector in Nigeria: Environmental and Economic Sustainability Assessment. Resources, 4, 412-433. https://doi.org/10.3390/resources4020412

[3] Ofoefule, A.U., Uzodinma, E.O. and Onukwuli, O.D. (2009) Biogas Development in Africa. International Journal of Physical Science, 4, 535-539.

[4] Lawal, A.K., Ajuebor, F.N. and Ojosu, J.O. (2001) Characteristic of Piggery Wastes Feeds Stock for Determination of Design Parameters to Biogas Digester Plant. Nigerian Journal of Research and Review in Science, 2, 193-198.

[5] Onwuliri, F.C., Onyimba, I.A. and Nwaukwu, I.A. (2013) Generation of Biogas from Cow Dung. Bioremediation and Biodegradation, S18, 002. https://doi.org/10.4172/2155-6199.S18-002

[6] Ajiboye, A.V., Lasisi, K.H. and Babatola, J.O. (2018) Evaluation of the Effect of Sodium Hydroxide Solution on Biogas Yield of Anaerobic Digestion of Poultry Waste and the Digestate. International Journal of Energy and Water Resources, 2, 23-31. https://doi.org/10.1007/s42108-018-0003-2

[7] Otun, T.F., Ojo, O.M., Ajibade, F.O. and Babatola, J.O. (2015) Evaluation of Biogas Production from the Digestion and Co-Digestion of Animal Waste, Food Waste and Fruit Waste. International Journal of Energy and Environmental Research, 3, $12-24$.

[8] EIA (2016) United State Energy Information Administration. Country Analysis Brief: Nigeria.

https://www.eia.gov/beta/international/analysis_includes/countries_long/Nigeria/ni geria.pdf

[9] Babatola, J.O. (2008) Comparative Study of Biogas Yield Pattern in Some Animal and Household Wastes. African Research Review, 2, 54-68.

https://doi.org/10.4314/afrrev.v2i4.41081

[10] Musa, B. and Raji, H.M. (2016) Quantitative and Qualitative Analysis of Biogas 
Produces from Three Organic Wastes. International Journal of Renewable Energy Research, 6, 299-305.

[11] Nwankwo, C.S., Eze, J.I. and Okoyeuzu, C. (2017) Design and Fabrication of 3.60 m3 Household Plastic Bio Digester Loaded with Kitchen Waste and Cow Dung for Biogas Generation. Scientific Research and Essays, 12, 130-141.

https://doi.org/10.5897/SRE2017.6516

[12] National Bureau of Statistics (2018) Nigerian Gross Domestic Product Report (Q4 and Full Year 2017).

[13] Okewale, A.O., Omoruwuo, F. and Ojaigho, R.O. (2016) Alternative Energy Production for Environmental Sustainability. British Journal of Renewable Energy, 1, 18-22. https://doi.org/10.1051/rees/2016040

[14] Chibueze, U., Okorie, N., Oriaku, O., Isu, J. and Peters, E. (2017) The Production of Biogas Using Cow Dung and Food Waste. International Journal of Materials and Chemistry, 7, 21-24.

[15] MWPS (2000) Manure Characteristics. Mid-West Plan Service MWPS-18.

[16] Dioha, I.J., Ikeme, C.H., Nafi'u, T., Soba, N.I. and Yusuf, M.B.S. (2013) Effect of Carbon to Nitrogen Ratio on Biogas Production. International Research Journal of Natural Sciences, 1, 1-10.

[17] Nnabuchi, M.N., Akubuko, F.O., Augustine, C. and Ugwu, G.Z. (2012) Assessment of the Effect of Co-Digestion of Chicken Dropping and Cow Dung on Biogas Generation. International Research Journal of Engineering Science, Technology and Innovation, 1, 238-243.

[18] Ogur, E.O. and Irungu, P. (2013) Design of a Biogas Generator. International Journal of Engineering Research and Applications, 3, 630-635.

[19] Wu, X., Yao, W., Zhu, J. and Miller, C. (2010) Biogas and CH4 Productivity by Co-Digesting Swine Manure with Three Crop Residues as an External Carbon Source. Bioresource Technology, 101, 4042-4047. https://doi.org/10.1016/j.biortech.2010.01.052

[20] McCarty, P.L. and Mosey, F.E. (1991) Modelling of Anaerobic Digestion Processes. Water Science \& Technology, 24, 17-33. https://doi.org/10.2166/wst.1991.0216

[21] De Baere, L. (2000) Anaerobic Digestion of Solid Waste: State-of-the-Art. Water Science and Technology, 41, 283-290. https://doi.org/10.2166/wst.2000.0082

[22] Manyi-Loh, C.E., Mamphwell, S.N., Meyer, E.L., Okoh, A.I., Makaka, G. and Simon, M. (2013) Microbial Anaerobic Digestion (Bio-Digesters) as an Approach to the Decontamination of Animal Wastes in Pollution Control and the Generation of Renewable Energy. International Journal of Environmental Research and Public Health, 10, 4390-4417. https://doi.org/10.3390/ijerph10094390

[23] Deublein, D.A. (2008) Biogas from Waste and Renewable Resources: An Introduction. John Wiley and Sons, Hoboken.

[24] Mata-Alvarez, J. (2003) Fundamentals of the Anaerobic Digestion Process. In: Mata-Alvarez, J., Ed., Biomethanization of the Organic Fraction of Municipal Solid Wastes, IWA Publishing Company, Amsterdam, 202-209.

[25] Meegoda, J.N., Li, B., Patel, K. and Wang, L.B. (2018) A Review of the Processes, Parameters, and Optimization of Anaerobic Digestion. International Journal of Environmental Research and Public Health, 15, 2224. https://doi.org/10.3390/ijerph15102224

[26] Roddy, D.J. (2012) Biomass and Biofuels-Introduction. In: Sayigh, A., Ed., Comprehensive Renewable Energy, Elsevier, Hoboken, 1-9. 
https://doi.org/10.1016/B978-0-08-087872-0.00501-1

[27] Christy, P.M., Gopinath, L.R. and Divya, D. (2014) Microbial Dynamics during Anaerobic Digestion of Cow Dung. International Journal of Plant, Animal and Environmental Sciences, 4, 86-94.

[28] Azman, S. (2016) Anaerobic Digestion of Cellulose and Hemiceullose in the Presence of Humic Acids. Wageningen University, Wageningen.

[29] Kigozi, R., Aboyade, A. and Muzenda, E. (2014) Biogas Production Using the Organic Fraction of Municipal Solid Waste as Feedstock. International Journal of Research in Chemical, Metallurgical and Civil Engineering, 1, 54-64.

[30] Ukpai, P.A. and Nnabuchi, M.N. (2012) Comparative Study of Biogas Production from Cow Dung, Cow Pea and Cassava Peeling Using 45 Litres Biogas Digester. Advances in Applied Science Research, 3, 1864-1869.

[31] Aladjadjiyan, A., Penkov, D., Verspecht, A., Zahariev, A. and Kakanakov, N. (2016) Biobased Fertilizers-Comparison of Nutrient Content of Digestate/Compost. Journal of Agriculture and Ecology Research International, 8, 1-7. https://doi.org/10.9734/JAERI/2016/25217

[32] Hansen, C.L. and Cheong, D.Y. (2013) Agricultural Waste Management in Food Processing. In: Kutz, M., Ed., Handbook of Farm, Dairy, and Food Machinery Engineering, Academic Press, Cambridge, 609-661. https://doi.org/10.1016/B978-0-12-385881-8.00023-9

[33] House, D. (2006) Complete Biogas Handbook. 3rd Edition, House Press, Culver City, CA, USA, 288 p.

[34] Gallert, C. and Winder, J. (2005) Bacterial Metabolism in Wastewater Treatment System. In: Jördening, H.J. and Winter, J., Eds., Environmental Biotechnology: Concepts and Applications, Wiley VCH, Weinheim, Chapter 1.

https://doi.org/10.1002/3527604286.ch1

[35] Stams, A.J.M. and Plugge, C.M. (2009) Electron Transfer in Syntrophic Communities of Anaerobic Bacteria and Archaea. Nature Reviews Microbiology, 7, 568-577. https://doi.org/10.1038/nrmicro2166

[36] Oyeleke, S.B., Onigbajo, H.O. and Ibrahim, K. (2003) Degradation of Animal Wastes (Cattle Dung) to Produce Methane (Cooking Gas). Proceeding of the Eighth Annual Conference of Animal Science Association of Nigeria, Enugu, 12-15 September, 168-169.

[37] Deepanraj, B., Sivasubramanian, V. and Jayaraj, S. (2014) Solid Concentration Influence on Biogas Yield from Food Waste in an Anaerobic Batch Digester. Proceeding on International Conference and Utility Exhibition on Green Energy for Sustainable Development, Pattaya, 19-21 March 2014, 1-4.

[38] Gaby, J.C., Zamanzadeh, M. and Horn, S.J. (2017) The Effect of Temperature and Retention Time on Methane Production and Microbial Community Composition in Staged Anaerobic Digesters Fed with Food Waste. Biotechnology for Biofuels, 10, 302. https://doi.org/10.1186/s13068-017-0989-4

[39] Verspecht, A. and Buysse, J. (2012) Improved Nutrient and Energy Management through Anaerobic Digestion.

https://cordis.europa.eu/docs/results/289/289712/final1-summary-inemad-final.pdf

[40] Okewale, A.O., Omoruwou, F. and Anih, C.E. (2018) Production of Biogas from Co-Digestion of Cow Dung, Saw Dust and Maize Husk. Advances in Chemical Engineering and Science, 8, 113-123. https://doi.org/10.4236/aces.2018.83008

[41] Nkoi, B., Lebele-Alawa, B.T. and Odobeatu, B. (2018) Design and Fabrication of a Modified Portable Biogas Digester for Renewable Cooking-Gas Production. Euro- 
pean Journal of Engineering Research and Science, 3, 21-29.

https://doi.org/10.24018/ejers.2018.3.3.647

[42] Vögeli, Y., Lohri, C.R., Gallardo, A., Diener, S. and Zurbrügg, C. (2014) Anaerobic Digestion of Biowaste in Developing Countries-Practical Information and Case Studies. https://www.ircwash.org/sites/default/files/2014-biowaste-eawag.pdf 